\title{
HUBUNGAN PERAN KELUARGA DENGAN TINGKAT KEBERHASILAN PENGOBATAN TBC PARU ANAK USIA SEKOLAH DI BALAI PENGOBATAN PENYAKIT PARU-PARU (BP.4) MEDAN
}

\author{
Rina Rahmadani Sidabutar* \\ Surel:elismihardjo@gmail.com
}

\begin{abstract}
Most of tuberculosis cases in children are caused by Mycobacterium tuberculosis bacteria around their houses. Children under 15 years old, including school-aged children 6 to 12 years of age, experience emotional disturbance which results in changes of the children behavior so that it will be very difficult to explain to a child about tuberculosis treatment procedure which takes about six until eight months. Therefore, it is necessary to find out how influential the family role is in the success rate of the treatment. Family has a very influential role in healing TB disease in children such as, consulting a doctor, accompanying the provision of medicines given through mouth, and also paying attention to the diet and nutrition of the children.The study was conducted with descriptive case study method. The sampling technique was accidental sampling with the sample size of 30 respondents out of 55 respondents. Data were collected by administering questionnaire and then were measured by the Rho Spearmen correlation test. The results showed a computerized statistical analysis identifying the relationship of family role which consisted of consulting a doctor, providing OAT through the mouth, and paying attention to diet and nutrition with TB treatment success in school-aged children with a significant level of 0.05. Contacting the doctor obtained a $p$ value of 0.013 which shows a low relationship. Giving OAT through mouth obtained a $p$ value of 0.026. This indicates a low relationship. Taking into account the diet and nutrition obtained $p$ value of 0.021. This also shows a low relationship. Therefore, it is expected that students and nurses can improve the quality of nursing care to increase family participation in achieving the success of TB treatment in school-aged children.
\end{abstract}

Keywords: family role, treatment success, pulmonary TB

\section{PENDAHULUAN}

\footnotetext{
* Rina Rahmadani Sidabutar, S.Kep.Ns,M.Kep. Dosen STIKES Flora Medan
} 
B erdasarkan data dari WHO tahun 1993 didapatkan fakta bahwa sepertiga penduduk bumi telah diserang oleh penyakit Tuberkulosis (TBC). Sekitar 8 juta orang dengan kematian pertahun. Diperkirakan dalam tahun 20022020 akan ada 1 miliar manusia terinfeksi, sekitar 5-10 persen berkembang menjadi penyakit dan 40 persen yang terkena penyakit berakhir dengan kematian. Demikian juga, kasus TBC pada anak terjadi sekitar 1,3 juta setiap tahun dan 450.000 di antaranya meninggal dunia (Agnes, 2011).

Jumlah anak berusia < 15 tahun adalah $40-50 \%$ dari jumlah seluruh populasi. Kebanyakan kasus TBC pada anak terinfeksi dengan Mycobacterium tuberkulosis di rumahnya oleh seseorang yang dekat padanya (Richard. 1999). Usia $<15$ tahun, diantaranya anak usia sekolah 6 sampai 12 tahun atau Late Childhood kebanyakan berada dalam keadaan tidak seimbang, anak mengalami gangguan emosional sehingga sulit untuk hidup bersama dan bekerja sama, mengakibatkan perubahan sikap nilai dan perilaku. Perilaku disiplin yang diterapkan oleh orangtua merupakan masalah yang serius bagi anak (Hurlock, 2007). Prosedur pengobatan pada kasus TBC terdiri dari 2 tahap yaitu, tahap intensif dan lanjutan, dengan lama pengobatan 6-8 bulan, hal ini akan sangat sulit untuk menjelaskan kepada seorang anak mengenai prosedur apa yang mungkin dilibatkan dalam terapi, atau untuk membujuk seorang anak kecil untuk menerima semua obat, terapi atau batasan-batasan yang diperlukan (Hastings, 2005).

Program penanggulangan yang tidak dilaksanakan dengan tepat merupakan masalah utama terapi TBC. Penderita dan keluarga harus tahu apa yang diharapkan mereka melalui instruksi lisan dan tulisan dalam bahasa ibunya. Sekurang-kurangnya $\quad 30-50 \%$ penderita yang memerlukan pengobatan jangka panjang tidak taat pada proses pengobatan, biasanya tidak mampu menentukan lebih dahulu penderita mana yang akan menjadi tidak teratur (Behram, 2012). Keluarga memainkan suatu peran bersifat mendukung selama masa penyembuhan dan pemulihan klien. Apabila dukungan semacam ini tidak ada, maka keberhasilan penyembuhan atau pemulihan sangat berkurang (Friedman, 2010).

\section{TINJAUAN PUSTAKA}

\section{Definisi Peran}

Peran mencakup harapan atau standar perilaku yang telah diterima oleh keluarga, komunitas dan kultur. Perilaku didasarkan pada pola yang ditetapkan melalui sosialisasi. Sosialisasi dimulai tepat setelah lahir, ketika bayi berespon terhadap orang dewasa dan orang dewasa berespon terhadap perilaku bayi (Potter\& Perry, 2015). 
Peran adalah serangkaian perilaku yang diharapkan oleh masyarakat yang sesuai dengan fungsi yang ada dalam masyarakat atau suatu pola sikap, perilaku, nilai dan tujuan yang diharapkan dari seseorang berdasarkan posisinya di masyarakat, misalnya sebagai orangtua, atasan, teman dekat dan sebagainya. Setiap peran berhubungan dengan penentuan harapan-harapan tertentu, apabila harapan tersebut dapat terpenuhi, rasapercaya diri seseorang akan meningkat. Sebaliknya, kegagalan untuk memenuhi harapan atas peran dapat menyebabkan penurunan harga diri atau terganggunya konsep diri seseorang (Hidayat, 2016).

Prinsip dasar pengobatan TBC pada anak tidak berbeda pada orang dewasa, tetapi ada beberapa hal yang memerlukan perhatian, pemberian obat baik pada tahap intensif maupun tahap lanjutan diberikan setiap hari secara teratur dalam jangka waktu yang cukup lama, pengawasan terhadap jadwal pemberian obat, keyakinan bahwa obat diminum dan dosis obat harus disesuaikan dengan berat badan anak.

\section{Keberhasilan Pengobatan}

Program Pembangunan Nasional (PROPENAS) pada sektor kesehatan. Salah satunya program upaya kesehatan, dimana sasaran yang akan dicapai oleh program ini adalah angka kesembuhan penyakit
TBC paru lebih dari $85 \%$ (Rachmat, 2014).

Di tingkat kabupaten, propinsi dan pusat, angka kesembuhan minimal harus dicapai adalah $85 \%$. Angka kesembuhan digunakan untuk mengetahui keberhasilan pengobat- an. Bila angka kesembuhan lebih rendah dari $85 \%$, maka harus ada informasi dari hasil pengobatan lainnya, yaitu berapa penderita yang digolongkan sebagai pengobatan lengkap, default atau drop-out atau lalai, gagal, meninggal dan pindah keluar (Depkes RI, 2016).

Obat TBC diberikan dalam bentuk kombinasi dari beberapa jenis, dalam jumlah cukup dan dosis tepat selama 6-8 bulan, agar semua kuman dapat dibunuh. Dosis tahap intensif atau awal dan tahap lanjutan diberikan sebagai dosis tunggal, sebaiknya diberikan pada saat perut kosong. Apabila paduan obat diberikan tidak adekuat atau jenis, dosis, dan jangka waktu pengobatan, kuman TBC akan berkembang menjadi kuman kebal obat atau resisten (Depkes RI, 2016).

Untuk melihat keberhasilan terapi, maka dapat di evaluasi pasien. Evaluasi pasien meliputi evaluasi klinis, bakteriologi, radiologi, dan efek samping obat, serta evaluasi keteraturan berobat.

a. Evaluasi klinis

- Pasien dievaluasi setiap 2 minggu pada 1 bulan pertama 
pengobatan selanjutnya setiap 1 bulan

- Evaluasi, respons pengobatan dan ada tidaknya efek samping obat serta ada tidaknya komplikasi penyakit

- Evaluasi klinis meliputi keluhan, berat badan, pemeriksaan fisik.

b. Evaluasi bakteriologi (0-2-6/9 bulan pengobatan)

- Tujuan untuk mendeteksi ada tidaknya konversi dahak

- Pemeriksaan dan evaluasi pemeriksaan mikroskopis dilakukan sebelum pengobatan dimulai,setelah 2 bulan pengobatan atau setelah fase intensif dan pada akhir pengobatan.

- Bila ada fasiliti biakan, dilakukan pemeriksaan biakan dan uji resistensi.

c. Evaluasi radiologi (0-2-6/9 bulan pengobatan)Pemeriksaan dan evaluasi foto toraks dilakukan pada

- Sebelum pengobatan

- Setelah 2 bulan pengobatan (kecuali pada kasus yang juga dipikirkan kemungkinan keganasan dapat dilakukan 1 bulan pengobatan)

- Pada akhir pengobatan

d. Evaluasi efek samping secara klinis
- Bila mungkin sebaiknya dari awal diperiksa fungsi hati, fungsi ginjal dan darah lengkap

- Fungsi hati, Serum Glutamic Oxaloacetic Transaminase (SGOT), Serum Glutamic Piruvat Transaminase (SGPT), bilirubin, fungsi ginjal : ureum, kreatinin, dan gula darah, serta asam urat untuk data dasar penyakit peserta atau efek samping pengobatan

- Asam urat diperiksa bila menggunakan pirazinamid

- Pemeriksaan visus dan uji buta warna bila menggunakan etambutol atau bila ada keluhan

- Pasien yang mendapat streptomisin harus diperiksa uji keseimbangan dan audiometri atau bila ada keluhan

- Pada anak dan dewasa muda umumnya tidak diperlukan pemeriksaan awal tersebut. Yang paling penting adalah evaluasi klinis kemungkinan terjadi efek samping obat. Bila pada evaluasi klinis dicurigai terdapat efek samping, maka dilakukan pemeriksaan laboratorium untuk memastikannya dan penanganan efek samping obat sesuai pedoman.

e. Evaluasi keteraturan berobat

- Yang tidak kalah pentingnya adalah evaluasi keteraturan berobat dan diminum / tidaknya obat tesebut. Dalam hal ini 
maka sangat penting penyuluhan atau pendidikan mengenai penyakit dan keteraturan berobat. Penyuluhan atau pendidikan dapat diberikan kepada pasien, keluarga dan lingkungannya.

- Ketidakteraturan berobat akan menyebabkan timbulnya masalah resistensi.

Kriteria pasien sembuh antara lain, BTA mikroskopis negatif dua kali atau pada akhir fase intensif dan akhir pengobatan dan telah mendapatkan pengobatan yang adekuat, pada foto toraks, gambaran radiologi serial tetap sama atau perbaikan dan bila ada fasiliti biakan, maka kriteria ditambah biakan negatif.

Evaluasi pasien yang telah sembuh antara lain, pasien TBC yang telah dinyatakan sembuh sebaiknya tetap dievaluasi minimal dalam 2 tahun pertama setelah sembuh, hal ini dimaksudkan untuk mengetahui kekambuhan. Hal yang dievaluasi adalah mikroskopis BTA dahak dan foto toraks. Mikroskopis BTA dahak 3,6,12 dan 24 bulan atau sesuai indikasi atau bila ada gejala, setelah dinyatakan sembuh. Evaluasi foto toraks $6,12,24$ bulan setelah dinyatakan sembuh atau bila ada kecurigaan TB kambuh (Perhimpunan Dokter Paru Indonesia, 2016).

\section{METODE PENELITIAN} Jenis Penelitian

Penelitian ini menggunakan Jenis deskriptif studi kasus, hal ini dilakukan dengan cara meneliti suatu permasalahan melalui suatu kasus yang terdiri dari unit tunggal, unit tunggal dapat berupa kelompok orang yang memiliki suatu masalah. Tujuan penelitian ini adalah untuk mengetahui secara intensif tentang latar belakang keadaan sekarang dan interaksi lingkungan sesuatu unit sosial, individu, kelompok, lembaga atau masyarakat (Setiadi, 2015).

\section{Lokasi dan Waktu Penelitian} Lokasi Penelitian

Penelitian dilaksanakan di Balai Pengobatan Penyakit ParuParu (BP.4) Medan.

\section{Waktu Penelitian}

Penelitian ini dilaksanakan pada tanggal 14 Februari sampai dengan 2 Maret 2017.

\section{Populasi dan Sampel \\ Populasi}

Populasi adalah keseluruhan subyek penelitian. Populasi dalam penelitian ini adalah keluarga anak dengan kasus ulangan TBC Paru di Balai Pengobatan Penyakit ParuParu (BP.4) Medan sebanyak55 keluarga.

\section{Sampel}

Sampel adalah sebagian atau wakil dari populasi (Nursalam. 
2015). Sampel dalam penelitian ini diambil dengan metode Acsidental Sampling dilakukan dengan mengambil kasus atau responden yang kebetulan ada atau tersedia, jumlah sampel sebanyak 30 keluarga (Notoatmodjo, 2012).

Kriteria-kriteria yang ditentukan oleh peneliti sebagai berikut :

a. Keluarga yang memiliki anak usia sekolah dengan kasus TB Paru berulang.

b. Keluarga yang memiliki anak usia sekolah yang sedang menjalani pengobatan pada tahap intensif maupun tahap lanjutan

c. Bisa berbahasa Indonesia.

d. Berkenan menjadi responden.

\section{Teknik Pengumpulan Data}

Pengumpulan data dilakukan dengan menggunakan kuesioner, yang disusun dan dimodifikasi oleh peneliti dengan mengacu kepada kerangka konsep dan tinjauan pustaka, terdiri dari 4 bagian yang berisi kuesioner menghubungi dokter, mendampingi pemberian obat-obatan yang diberikan lewat mulut, memperhatikan diet dan nutrisi serta keberhasilan pengobatan.

Kuesioner tersebut akan dibagikan kepada responden yang sesuai dengan kriteria peneliti, kemudian peneliti menunggu responden menjawab kuesioner yang diberikan dan tidak tertutup kemungkinan untuk responden menanyakan pertanyaan yang dianggap kurang jelas kepada peneliti.

\section{HASIL PENELITIAN DAN \\ PEMBAHASAN}

\section{Hasil Penelitian}

Hasil penelitian yang telah di lakukan peneliti di Balai Pengobatan Paru-Paru (BP.4) Medan. Dalam penelitian ini dapat digambarkan secara umum karakteristik dari 30 responden yang diteliti, yang diperoleh dan diolah dengan teknik koefisien korelasi bivariat dan menggunakan uji korelasi Sperman Rho. Hasil penelitian yang dilakukan terhadap responden dapat dilihat pada tabel-tabel di bawah ini.

\section{Peran Keluarga Terhadap Pengobatan TB Paru Pada Usia Anak Sekolah}

Tabel .1Distribusi Frekuensi Dan Persentase Berdasarkan Peran

Keluarga Terhadap Pengobatan TB Paru Pada Usia Sekolah Di

Balai PengobatanPenyakit ParuParu (BP.4) Medan

\begin{tabular}{|c|c|c|}
\hline Peran keluarga & Frekuensi & $\%$ \\
\hline $\begin{array}{c}\text { Konsultasi dengan dokter } \\
\text { Teratur } \\
\text { Tidak teratur }\end{array}$ & $\begin{array}{c}28 \\
2\end{array}$ & $\begin{array}{r}93.3 \\
6.7\end{array}$ \\
\hline Total & 30 & 100 \\
\hline $\begin{array}{l}\text { Membantupemberian } \\
\text { OAT } \\
\\
\\
\text { Baik } \\
\text { Tidak baik }\end{array}$ & $\begin{array}{c}22 \\
8\end{array}$ & $\begin{array}{l}73.3 \\
26.7\end{array}$ \\
\hline Total & 30 & 100 \\
\hline $\begin{array}{l}\text { Memperhatikan diet dan } \\
\text { nutrisi } \\
\text { Baik } \\
\text { Tidak baik }\end{array}$ & $\begin{array}{l}20 \\
10\end{array}$ & $\begin{array}{l}66.7 \\
33.3\end{array}$ \\
\hline Total & 30 & 100 \\
\hline
\end{tabular}


Tabel 1 berdasarkan peran keluarga dalam berkonsultasi dengan dokter, menunjukkan peran keluarga yang teratur $(93.3 \%)$, peran keluarga yang tidak teratur $(6.7 \%)$. Berdasarkan peran keluarga dalam membantu pemberian OAT melalui mulut, menunjukkan peran keluarga yang baik (73.3\%), peran keluarga yang tidak baik (26.7\%). Berdasarkan peran keluarga dalam memperhatikan diet dan nutrisi, menunjukkan peran keluarga yang baik (66.7\%), peran keluarga yang tidak baik (33.3\%).

Tingkat Keberhasilan Pengobatan TB Paru Pada Anak Usia Sekolah

Tabel .2Distribusi Frekuensi Dan Persentase Berdasarkan Tingkat Keberhasilan Pengobatan TB Paru Pada Anak Usia Sekolah Di Balai PengobatanPenyakit ParuParu (BP.4) Medan

\begin{tabular}{|c|c|c|}
\hline $\begin{array}{c}\text { Keberhasilan } \\
\text { pengobatan }\end{array}$ & Frekuensi & $\%$ \\
\hline $\begin{array}{c}\text { Berhasil } \\
\text { Tidak berhasil }\end{array}$ & 16 & 53.3 \\
& 14 & 46.7 \\
\hline Total & 30 & 100.00 \\
\hline
\end{tabular}

Tabel 2 menunjukkan bahwa keberhasilan pengobatan yang berhasil (53.3\%), keberhasilan pengobatan yang tidak berhasil (46.7\%).

Tabulasi SilangPeran Keluarga Dengan Tingkat Keberhasilan
Pengobatan TB Paru PadaAnak Usia Sekolah

Tabel .3Tabulasi silang Peran Keluarga Dalam Berkonsultasi Dengan Dokter Dengan Tingkat Keberhasilan Pengobatan TB Paru Pada Anak Usia Sekolah Di Balai Pengobatan Penyakit ParuParu (BP.4) Medan

\begin{tabular}{|c|c|c|c|c|c|c|}
\hline \multirow[b]{2}{*}{$\mathrm{N}_{0}$} & \multirow{2}{*}{$\begin{array}{c}\text { Peran keluarga } \\
\text { dalam Berkonsultasi } \\
\text { dengan dokter }\end{array}$} & \multicolumn{4}{|c|}{ Keberhasilan pengobatan } & \multirow[b]{2}{*}{ Total } \\
\hline & & $\begin{array}{c}\text { Tidak } \\
\text { berhasil }\end{array}$ & $\%$ & Berhasil & $\%$ & \\
\hline 1 & Tidak Teratur & 2 & 6.7 & 0 & .0 & 2 \\
\hline \multirow[t]{3}{*}{2} & Teratur & 12 & 40.0 & 16 & 53.3 & 28 \\
\hline & Total & 14 & 46.7 & 16 & 53.3 & 30 \\
\hline & \multicolumn{5}{|c|}{ Nilai p } & 0.013 \\
\hline
\end{tabular}

Tabel 3 menunjukkan peran keluarga yang tidak teratur dalamberkonsultasi dengan dokter $67 \%$ dengan tingkat keberhasilan pengobatan TB Paru, tidak berhasil $6.7 \%$, berhasil $.0 \%$. Peran keluarga yang teratur dalam berkonsultasi dengan dokter $93.3 \%$ dengan tingkat keberhasilan pengobatan TB Paru, tidak berhasil 40.0, berhasil 53.3\%. Dengan taraf signifikan 0.05 , diperoleh nilai $\mathrm{p}$ dalam berkonsultasi dengan dokter sebesar 0.013 , berarti terdapat hubungan yang rendah.

Tabel .4Tabulasi silang Peran Keluarga Dalam Memberikan OAT Dengan Tingkat Keberhasilan Pengobatan TB Paru Pada Anak Usia Sekolah Di 
Balai Pengobatan Penyakit ParuParu (BP.4) Medan

\begin{tabular}{|c|c|c|c|c|c|c|}
\hline \multirow{2}{*}{ No } & Peran & \multicolumn{3}{|c|}{ Keberhasilan pengobatan } & \multirow{2}{*}{ keluarga } \\
\cline { 3 - 6 } & $\begin{array}{c}\text { dalam } \\
\text { memberikan } \\
\text { OAT }\end{array}$ & $\begin{array}{c}\text { Tidak } \\
\text { berhasil }\end{array}$ & $\%$ & Berhasil & $\%$ & Total \\
\hline 1 & Tidak baik & 3 & 10.0 & 5 & 16.7 & 8 \\
\hline 2 & Baik & 11 & 36.7 & 11 & 36.7 & 22 \\
\hline & Total & 14 & 46.7 & 16 & 53.3 & 30 \\
\hline & \multicolumn{6}{|c|}{ Nilai p } \\
\hline
\end{tabular}

Tabel 4 menunjukkan peran keluarga yang tidak baik dalam memberikan OAT melalui mulut 26.7\% dengan tingkat keberhasilan pengobatan TB Paru, tidak berhasil $10.0 \%$, berhasil $16.7 \%$. Peran keluarga yang baik dalam memberikan OAT melalui mulut 73.3\% dengan tingkat keberhasilan pengobatan TB Paru, tidak berhasil $36.7 \%$, berhasil $36.7 \%$. Dengan taraf signifikan 0.05 , di peroleh nilai $\mathrm{p}$ memberi OAT melalui mulut sebesar 0.026, berarti terdapat hubungan yang rendah.

\section{Tabel.5Tabulasi silang Peran Keluarga Dalam \\ Memperhatiakan Diet Dengan Tingkat Keberhasilan Pengobatan TB Paru Pada Anak Usia Sekolah Di Balai Pengobatan Penyakit Paru-Paru (BP.4) Medan}

\begin{tabular}{|c|c|c|c|c|c|c|}
\hline \multirow{2}{*}{ No } & Peran keluarga dalam & \multicolumn{3}{|c|}{ Keberhasilan pengobatan } & \multirow{2}{*}{ Total } \\
\cline { 3 - 6 } & memperhatiakan diet & $\begin{array}{c}\text { Tidak } \\
\text { berhasil }\end{array}$ & $\%$ & Berhasil & $\%$ & \\
\hline 1 & Tidak baik & 3 & 10.0 & 7 & 23.3 & 10 \\
\hline 2 & Baik & 11 & 36.7 & 9 & 30.0 & 20 \\
\hline & Total & 14 & 46.7 & 16 & 53.3 & 30 \\
\hline & Nilai p \\
\hline
\end{tabular}

Tabel 5 menunjukkan peran keluarga yang tidak baik dalam memperhatiakn diet $33.3 \%$ dengan tingkat keberhasilan pengobatan TB Paru, tidak berhasil $10.0 \%$, berhasil $23.3 \%$. Peran keluarga yang baik dalam memberikan OAT melalui mulut $66.7 \%$ dengan tingkat keberhasilan pengobatan TB Paru, tidak berhasil $36.7 \%$, berhasil $30.0 \%$. Dengan taraf signifikan 0.05, di peroleh nilai $p$ memperhatikan diet sebesar 0.021, berarti terdapat hubungan yang rendah.

\section{PEMBAHASAN}

Setelah dilakukan penelitian pada responden yang pelaksanaannya dimulai pada tanggal 14 Februari sampai 2 Maret 2017 dan sampel sebanyak 30 Keluarga. Berdasarkan dari hasil penelitian, sehingga dapat didiskusikan satu persatu sesuai dengan tabel yang tersedia di atas. Adapun pembahasan sebagai berikut.

Peran Keluarga Terhadap Pengobatan TB Paru Pada Usia Sekolah di Balai Pengobatan Penyakit Paru-Paru (BP.4) Medan.

Diagnosis Tuberkulosis anak menurut Pertemuan Dokter Anak pulmunologi tahun 2015 harus dengan pengamatan seksama tentang adanya gejala klinis, kontak erat serumah penderita TBC maka 
dapat dipastikan dengan dengan pemeriksaan dahak positif, pemeriksaan yang harus dilakukan adalah roentgen, tes mantouxt. Sering terjadi hanya dengan melakukan pemeriksaan satu jenis pemeriksaan saja, anak sudah divonis dengan penyakit TBC. Seharusnya pemeriksaan harus dilakukan secara lengkap dan teliti seperti di atas. Karena sulitnya mendiagnosis TBC pada anak dan kosekuensi lamanya pengobatan maka bila meragukan lebih baik dikonsultasikan atau dikonfirmasikan ke Dokter Spesialis Paru Anak. (Ikatan Dokter Anak Indonesia, 2015).

Berdasarkan hasil penelitian Hubungan Peran Keluarga Dengan Tingkat Keberhasilan Pengobatan TB Paru Pada Anak Usia Sekolah Di Balai Pengobatan Penyakit ParuParu (BP.4) Medan Tahun 2009, dari karakteristik peran keluarga dalam berkonsultasi dengan dokter, menunjukkan peran keluarga yang teratur (93.3\%), peran keluarga yang tidak teratur $(6.7 \%)$.

Sehat bukan berarti tidak sakit, dengan kata lain, kalau tidak sakit, belum tentu sehat apalagi bugar, tapi keluarga selalu mengabaikan kesehatan, menunggu sampai jatuh sakit, karena harga obat dan biaya perawatan rumah sakit amat mahal. Untuk melindungi kesehatan, mungkin keluarga bisa memilih menghubungi dokter sebagai mitra dalam memelihara kesehatan. Bila berhadapan dengan suatu masalah khusus yang tak mampu ditanggulangi, dokter bertindak sebagai koordinator dalam merencanakan konsultasi atau rujukan yang diperlukan. (Surendro Djati, 2014).

Berdasarkan peran keluarga dalam membantu pemberian OAT melalui mulut, menunjukkan peran keluarga yang baik $(73.3 \%)$, peran keluarga yang tidak baik (26.7\%). Berdasarkan peran keluarga dalam memperhatikan diet, menunjukkan peran keluarga yang baik (66.7\%), peran keluarga yang tidak baik $(33.3 \%)$.

TB Paru dapat disembuhkan, apabila pasien berobat dengan tekun dan teratur. Sebelum dokter atau petugas kesehatan menyatakan pasien telah benar-benar sembuh, pasien tidak boleh berhenti berobat. Bila pasien berhenti berobat sebelum sembuh, penyakitnya dapat kambuh kembali dan akan lebih sulit diobati.

Karena itu peran pasien sendiri maupun keluarga dalam mengawasi minum obat sangat penting, karena itu diperlukan DOTS. "DOTS (Directly Observed Treatment Short Course) atau Pengawasan Langsung Menelan Obat Jangka Pendek adalah suatu cara pengobatan TB Paru dimana setiap penderita TB Paru yang ditemukan harus diawasi secara langsung agar menelan obat secara 
teratur selama 6 bulan." (Kismed Akhmad, 2013).

Peran keluarga dapat meningkatkan keberhasilan pengobatan pada anak sedang sakit dengan meningkatkan kesehatan mental individu atau keluarga secara langsung. Peran keluarga merupakan dukungan yang dipandang oleh anggota keluarga sebagai sesuatu yang dapat diperoleh keluarga untuk mengatasi masalahnya (Friedman, 2010), melalui peran keluarga seseorang merasakan kenyamanan, perhatian dan penghargaan.

\section{Keberhasilan Pengobatan TB} Paru Pada Usia Sekolah di Balai Pengobatan Penyakit Paru-Paru (BP.4) Medan.

Berdasarkan hasil penelitian menunjukkan bahwa keberhasilan pengobatan, dari jawaban 30 responden, didapat bahwa tingkat keberhasilan pengobatan TB paru pada anak usia sekolah, berhasil $(53.3 \%)$, keberhasilan pengobatan yang tidak berhasil (46.7\%), sesuai dengan strategi DOTS yang mengupayakan agar penderita yang telah menerima obat / resep obat untuk selanjutnya tetap membeli / mengambil obat, minum obat secara teratur, kembali kontrol untuk menilai hasil pengobatan. Dengan strategi DOTS, maka tujuan pengobatan yang sesungguhnya dapat dipenuhi yaitu menyembuhkan, mencegah kematian, mencegah kekambuhan atau timbulnya resistensi terhadap OAT dan memutuskan rantai penularan. Diketahui dengan banyaknya faktor yang harus diperhatikan yang sangat mempengaruhi keberhasilan pengobatan, seperti lamanya waktu pengobatan, kepatuhan serta keteraturan penderita untuk berobat, daya tahan tubuh, juga faktor sosial ekonomi penderita yang tidak kalah pentingnya.

Tidak berhasil sebanyak (46.7\%), beberapa keadaan diduga merupakan faktor yang memegang peranan penting dalam meningkatnya infeksi TBC pada saat ini, antara lain, memburuknya kondisi sosial ekonomi, belum optimalnya fasilitas pelayanan kesehatan masyarakat, meningkatnya jumlah penduduk yang tidak mempunyai tempat tinggal, meningkatnya infeksi HIV, daya tahan tubuh yang lemah atau menurun, virulensi dan jumlah kuman yang meningkat.

Hubungan Peran Keluarga Dengan Tingkat Keberhasilan Pengobatan TB Paru Pada Anak Usia Sekolah di Balai Pengobatan Penyakit Paru-Paru (BP.4) Medan.

Dari hasil penelitian berdasarkan analisis komputerisasi dengan menggunakan uji Spearmen Rho, untuk melihat hubungan dengan tingkat signifikansi masing- 
masing variabel yaitu, hubungan antara peran keluarga dengan tingkat keberhasilan pengobatan TB Paru pada anak usia sekolah di Balai Pengobatan Penyakit Paru-Paru (BP.4) Medan. Hubungan peran keluarga yang terdiri dari, berkonsultasi dengan dokter, memberi OAT melalui mulut, memperhatikan diet dengan keberhasilan pengobatan TB paru pada anak usia sekolah dengan taraf signifikan 0.05 , diperoleh nilai $\mathrm{p}$ berkonsultasi dengan dokter sebesar 0.013 , berarti terdapat hubungan yangrendah. Nilai $\mathrm{p}$ memberi OAT melalui mulut sebesar 0.026 , berarti terdapat hubungan yang rendah. Nilai p memperhatikan diet sebesar 0.021 , berarti terdapat hubungan yang rendah. Dengan demikian dapat di interpretasikan semakin baik peran yang di berikan keluarga terhadap anak, maka tingkat keberhasilan pengobatan semakin baik pula.

Hasil penelitian ini sesuai dengan pendapat yang di kemukakan oleh Cooper dan Smith (1985), bahwa peran keluarga secara langsung meningkatkan keberhasilan pengobatan dan secara tidak langsung meningkatkan derajat kesehatan. Lingkungan social yang mendukung merupakan pengaruh positif yang kuat terhadap kesehatan anak, sehingga ditemukan hubungan yang signifikan antara peran keluarga dengan tingkat keberhasilan pengobatan TB paru pada anak usia sekolah di Balai Pengobatan Penyakit Paru-Paru (BP.4) Medan.

Berdasarkan faktor tersebut dapat diasumsikan bahwa keberhasilan pengobatan sangat dipengaruhi oleh keluarga, karena apabila perilaku keluarga yang tidak baik kepada pasien maka proses penyembuhan akan sulit dicapai bahkan mungkin pasien akan semakin parah. Oleh karena itu diharapkan peran serta keluarga dalam perawatan untuk mencapai keberhasilan pengobatan.

\section{KESIMPULAN DAN SARAN \\ Kesimpulan}

Berdasarkan hasil analisa dan pembahasan dengan hasil penelitian, maka diambil kesimpulan sebagai berikut :

a. Berdasarkan peran keluarga terhadap pengobatan TB paru pada usia sekolah di Balai Pengobatan Penyakit Paru-Paru (BP.4) Medan, berdasarkan karakteristik peran keluarga dalam menghubungi dokter, diperoleh nilai $\mathrm{p}$ menghubungi dokter sebesar $0.013(\mathrm{p}<0.05)$, berarti terdapat hubungan.

b. Berdasarkan peran keluarga terhadap pengobatan TB paru pada usia sekolah di Balai Pengobatan Penyakit Paru-Paru (BP.4) Medan, berdasarkan karakteristik peran keluarga dalam memberi OAT melalui mulut, di peroleh nilai $\mathrm{p}$ sebesar 
$0.026(\mathrm{p}<0.05)$, berarti terdapat hubungan.

c. Berdasarkan peran keluarga terhadap pengobatan TB paru pada usia sekolah di Balai Pengobatan Penyakit Paru-Paru (BP.4) Medan, berdasarkan karakteristik peran keluarga dalam memperhatikan diet dan nutrisi, di peroleh nilai $p$ sebesar $0.021 \quad(p<0.05), \quad$ itu berarti terdapat rendah.

\section{Saran}

a. Tempat Penelitian

Dalam melaksanakan asuhan keperawatan kepada keluarga yang salah satu anggota keluarga menderita TB Paru, hendaknya perawat mampu menambah pengetahuan keluarga tentang perawatan dan pengobatan TB Paru dengan cara memberikan pendidikan kesehatan setiap kali keluarga dating mengambil OAT.

b. Keluarga

Disarankan kepada keluarga agar dapat menambah pengetahuan dengan lebih sering bertanya tentang perawatan dan pengobatan pasien TB Paru kepada dokter atau perawat di BP.4 Medan, sehingga keluarga dapat memahami dan memperlakukan anak lebih baik.

c. Peneliti selanjutnya

Diharapkan peneliti selanjutnya dapat lebih menyempurnakan karya tulis ini, dengan meneliti faktor-faktor yang mempengaruhi keberhasilan pengobatan TB Paru dan faktorfaktor yang mempengaruhi peran keluarga untuk meningkatkan keberhasilan pengobatan.

\section{DAFTAR PUSTAKA}

Ali, Z, (2015). Pengantar KeperawatanKeluarga.EGC,J akarta.

Achjar, K.H.A. (2010). Asuhan keperawatan keluarga:Bagi mahasiswa keperawatan dan praktisi perawat perkesmas. Jakarta: Sagung seto.

Arikunto, S. (2015). Prosedur Penelitian Suatu

PendekatanPraktek. Rineka Cipta,Jakarta.

Amira, P. (2015). Peberantasan Penyakit Paru dan Strategi Dots, www.library.usu.ac.id. Di akses tanggal 27 Desember 2010.

Brunner \& Suddarth. (2015). Buku Ajar Keperawatan Medikal Bedah, Edisi 8, Volume 1. EGC, Jakarta.

Chandra, B. (2010). Ilmu Kedokteran pencegahan \&Komunitas. EGC, Jakarta.

Depkes RI. (2001). Panduan Pengawasan Menelan Obat TBC. Balai Pustaka,Jakarta. Efendy, F, Makhfudli, I. (2009). Keperawatan Kesehatan 
Kounitas. Salemba Medika, Jakarta.

Friedman, M.M, Bowden, V.R, and Jones, E.G. (2010). Family nursing: Research theory, practice . 5th Edition.Prentice Hall, New Jersey.

Friedman, M.M, Bowden, V.R, and Jones, E.G. (2010). Family nursing: Research theory, practice . 5th Edition. Prentice Hall, New Jersey.

Gunarso, S. (2010). Psikologi Perawat. BPK Gunung Mulia, Jakarta.

Hidayat, A. A. (2011).Metode Penelitian Keperawatan dan Tehnik Analisis Data. Salemba Medika, Jakarta.

Iswanti. (2012). Peran Keluarga Dalam Merawat AnggotaKeluarga Yang Menderita TB Paru di Wilayah KerjaPuskesmas kasian I Kab. Bantul Yogyakarta; Tidak Dipublikasikan.

Notoadmodjo, S. (2012). Metode Penelitian Kesehatan.Rineka Cipta, Jakarta. 